\title{
ANTI-CORRUPTION MEASURES FOR CORPORATE SECURITY
}

\author{
Natasha Georgieva Hadji Krsteski \\ University MIT, Faculty of Security, Skopje, Macedonia \\ natashageorgievaivanovska@gmail.com
}

\author{
Original Scientific Paper \\ doi:10.5937/jouproman5-13490
}

\begin{abstract}
Corporate security should commit to ethical management and raising the quality of companies and markets through improving cooperation and transparency by applying anticorruption measures such as accepting a code of ethics; respect and follow international business principles for dealing with bribery; improve their transparency - via access to information; involvement in politics to protect persons who disclose corruption cases; and improving corporate governance - through active mutual discussions on adjustment of legal regulations. Research methods used in the paper are: qualitative analysis of secondary data obtained from relevant institutions. Results obtained from the survey include fighting corruption in corporations must find a unique solution that is long-term strategy developed transparent society crucial criteria and principles to meet the political criteria by the fulfillment of anti-corruption standards; it requires continuous cooperation of public and private sector, NGOs and the general corpus of all stakeholders in the country against corruption; the lack of a legal framework or platform for establishing public and private partnerships, is an important factor for anti-corruption measures to improve corporate governance; mechanisms for cooperation does not seem sufficiently developed between the public, private, political and civil society; the most important factor to tackle corruption is to adopt a law on public prosecutors and determination of higher norms and standards. Conclusions drawn from the survey: in the area of pre-trial procedure requires shifting responsibilities of Interior Ministry body training in the area of the judicial system; it is necessary to change the Criminal Code and Criminal Procedure Code by changing certain legal provisions which refer to the Agency for money laundering SCCP, a financial police and overall legislation.
\end{abstract}

Keywords: anti-corruption measures, corporate security, Law, Code of Ethics.

\section{INTRODUCTION}

Corruption is performing or abuse of authority or of public interest or interest of another person, or conflicts of interest in the performance of corporate management or delegated powers. In this paper, the subject of analysis is exploring how corruption occurs in economically unstable corporations in absence of appropriate legislation or through unstable infrastructure control and supervision of law enforcement and anti-corruption measures to ensure corporate security. The negative effects of corrupt activities are: erosion of democratic climate, indifference to domestic and foreign investors, and loss of public confidence in corporate security.

The purpose of the paper is the application of appropriate methodological framework for qualitative data analysis, to elaborate the issues that are closely related to anticorruption measures providing of corporate security, such as: lack of law on financing of political parties constitutes a source of corrupt behavior and endangering corporate security; shortage and mismatch of the Public Procurement Law with European directives, standardize procedures and procedures because of the unequal treatment of public contracts in which as parties appear corporations, thus neglecting corporate security; Ministries must make systematic analysis to prevent corruption in corporations and ensuring corporate security; 
awareness of the discretion of the individual through a standard procedure and resolving the problem of providing corporate security; strengthening the position, capacity and efficiency of the institutions of control and supervision of corporate security through the application of anticorruption measures; formulation and adoption of ethical codes of conduct for the provision of corporate security.

\section{ANTI-CORRUPTION MEASURES FOR PREVENTION CORRUPTION AND STENGHTEN THE INTEGRITY OF THE PRIVATE SECTOR}

Regarding the problem of underdeveloped measures to prevent corruption and strengthen the integrity of the private sector, the analysis in the paper identifies four issues - indicators of the condition. Company Law provides robust provisions for prevention and treatment in conflicts of interest, and the prevention of corruption. Hence, the State program focuses on voluntary measures for the prevention of corruption and conflict of interest. Action plan of the State program provides activities for the provision of corporate security through the adoption of codes of conduct for the correct properly and conscientiously carry out business activities to prevent conflicts of interest and application of best practices in cooperation between private and public entities. Although the country there are a number of models of codes of conduct, they do not contain specific provisions on donations, sponsorships and public procurement with a high risk of corruption and conflict of interest, and provisions to encourage the reporting of violations in the codes and protection of applicators not sufficiently detailed. Another disadvantage of their application is the same monitoring (European Commission, 2016).
In addition, there are incentives for developing corporate programs for adherence to laws and regulations, and ethical behavior. The compliance with the regulations as an internal function is mandatory for some businesses, for example, banks and investment funds. Local regulations shall require companies to dispose of and to submit data on their nominal but not beneficial ownership and databases do not allow for simple and quick check of ultimate beneficial ownership and control of enterprises. Only the companies from certain activities with increased risk of money laundering are required to provide data for the ultimate ownership of the customer. More transparency is needed for recipients of public funds, as well as enhancement of information and supervision in the sphere of restrictions on private sector engagement to former officials. Regulation with respect to financial reporting, auditing and accounting in certain segments even exceeds international standards, but greater education within the profession on how to prevent and detect corruption (UN, 2016).

\subsection{General recommendations on the implementation of anti-corruption measures to prevent corruption and strengthen the integrity of the private sector}

Based on the analysis made the following general recommendations for problem 1 undeveloped measures to prevent corruption and strengthen the integrity of the private sector, and they are further developed in part with the findings of the analysis and, in the review and prioritization of recommendation (Business Anti-Corruption Portal, 2016): 
- encouraging the development and application of appropriate standards and procedures to safeguard the integrity of private sector entities (priority 1);

- the establishment of an updated database for verification of beneficial ownership and ultimate control over enterprises and ensuring their accessibility (priority 2);

- strengthening the application of limitations relating to the activities of the former administration employees (priority $1)$;

- improving and centralizing of online publication of the persons from the private sector, who received some form of public assets (eg. subsidies, state aid, public procurement), the same size and purpose (priority 2).

\section{ANTI-CORRUPTION MEASURES FOR CORRUPTION AND CONFLICT OF INTEREST IN THE PRIVATE SECTOR}

About problem 2 - lack of knowledge about corruption and conflicts of interest in the private sector, the analysis in the paper determine three issues-indicators for the condition. In accordance with the State program, the State Commission for Prevention of Corruption (SCPC) sign a memorandum of cooperation for mutual support with several representatives of the business sector (chambers of commerce, clusters and employers' organizations), which, among other things, refers to the exchange of available information and cooperation in the implementation of education and training. An absence of specific legal provisions to encourage reporting of suspicions of corruption and other illegal activities in the private sector and protection of persons who carry out such reporting, but SCPC in cooperation with the Ministry of Justice is already working on devising an appropriate system
(SCCP, 2015). Although it provided appropriate action by the program is not held special training on prevention of corruption in the private sector, and cooperation with the sector takes place at the level of consultation and information on anti-corruption measures initiated by the SCPC. The issue of anti-corruption appears on the agenda of the business sector in communication with the authorities, but generally not a priority. Overall, the business sector insufficiently encourages or supports civil society in the fight against corruption. The issue of corruption and anti-corruption in the private sector remains under-explored.

2.1. General recommendations on the implementation of anti-corruption measures for lack of knowledge about corruption and conflicts of interest in the private sector

Based on the analysis made the following general recommendations for problem 2 lack of knowledge about corruption and conflicts of interest in the private sector, and they are further developed in part with the findings of the analysis and, in the review and prioritization of recommendations (SCCP, 2015):

- Promoting cooperation between law enforcement authorities and businesses (priority 1);

- Encouraging the authorities by the private sector for preventing and repressing corruption (priority 2); and

- Work with the financial support of anticorruption civil society initiatives by the private sector (priority 1). 


\section{ANTI-CORRUPTION MEASURES BASED ON LAW ON PROTECTION OF COMPETITION}

About problem 3 - lack of information about the law on protection of competition and insufficient capacity of the Commission for Protection of Competition (CPC) enforcement agencies, the analysis found two issues-indicators for the condition. It is still necessary staffing and financial strengthening of the CPC, which is recognized in the State Program. CPC held several meetings with representatives of other authorities to strengthen interinstitutional cooperation, but yet remains to result in enhanced sharing of information. Observed is insufficient awareness among contracting authorities and businesses in terms of prohibited agreements, the role of the authorities and the possibilities to prevent corruption and to overcome this problem and made two guides intended for contracting authorities. Although is provided by the program which is not yet amended by Article 283 of the criminal code (Center for Studying Democracy (CSD), (2016). The penalties provided for him for the responsible persons in legal entities prevent establishment of that program would motivate companies to report cases of cartels and other prohibited agreements. Within educations held by the Bureau of Public procurement contracts bodies was observed under-representation of judges, which has a negative impact on the quality of judicial proceedings relating to fraud in public procurement.
3.1. General recommendations on the implementation of anti-corruption measures insufficient information on the law on protection of competition and insufficient capacity of the Commission for Protection of Competition (CPC) for law enforcement

Based on the analysis we made the following general recommendations for problem 3 - lack of information on the law on protection of competition and insufficient capacity of the Commission for Protection of Competition (CPC) for law enforcement, and they are further developed in part with the findings of the analysis and section for review and prioritization of recommendations (Nuredinoska, E; Sazdevski M. Gjuzel, B., 2014):

- Improving skills, human resources potential of state bodies and mechanisms for the prevention and detection of prohibited agreements involving bidders (private corporations) in public procurement (priority 1); and

- Further education and support to business entities for regulation related to the protection of competition and its implementation (priority 2 ).

\section{CODE OF BUSINESS ETHICS AS CORRUPTION MEASURE CORPORATE SECURITY}

In Macedonia there are at least three general models of codes of business ethics, some of which were developed or promoted in cooperation with the state (Kambovski V., Naumovski, P., 2002):

- "Business Code of Ethics" promoted by the Business Confederation and the State Commission for Prevention of Corruption; 
- "Code of Business Ethics and Conduct of Joint Stock Companies" and "Code of Business Ethics and Conduct for SMEs" prepared by Transparency International in cooperation with the Chamber of Commerce and the Economic Chamber of North-West Macedonia.

Macedonian Stock Exchange has a Code of Corporate Governance for the companies that are listed on the stock exchange. It is mandatory for companies listed on the segment of Super quotation, and they are required annually to submit a report with a statement on whether the company has applied the principles and each of the provisions of the Code, and for those that are not applied to give clarification on the reasons for that the same does not apply. The NGO sector is also active in promoting the framework for anti-corruption programs of the enterprises. For example, in 2010 has been translated and published in Macedonian Initiative Transparency International "Business principles to combat bribery." However, the general model codes do not contain specific provisions on donations and sponsorships and public procurement with a high risk of corruption and conflict of interest, and provisions to encourage the reporting of violations in the codes, laws and protection of the applicants not sufficiently detailed. There are more ethical codes at the level of individual industry or profession such (Business Anti-Corruption Portal, 2016):

- Ethical Code of intermediaries in trade of real estate Group real estate agents with the Chamber of Commerce;

- Ethical Code of advisers promoted by the Agency for Promotion of Entrepreneurship;

- Code of Ethics of PR specialists of the Association of public relations;

- Code of Ethics for members of the Association of Public Relations; and

- Code of Conduct for lawyers, legal associates and legal interns of the Bar.
For certain categories of businesses there is a legal obligation for the development and application of codes of ethics and introduction of monitoring compliance of the regulations. According to Article 93 of the Law on Banks Board of Directors shall draw up a code of ethics, and under Article 100 , persons with special rights and responsibilities shall every six months, a written statement on the existence of a conflict of interest.

Under Article 99 of the same law the board of a bank shall appoint a person or organize an inspection of compliance of the bank with the regulations, in order to identify and monitor the compliance risk of the bank's regulations. Risk of non-compliance with the regulations are considered risk measures imposed by the National Bank, the financial losses and reputational risk as a result of the failures in alignment of the bank's regulations. To control the compliance of the bank's regulations shall be submitted monthly reports to the board and quarterly report to the Supervisory Board. Executing these obligations envisaged fine for the bank, the person responsible for a person with special rights and powers in the bank. According to Article 21 of the law on investment funds, management companies of investment funds should adopt a code of conduct in the operation, and rules on conflicts of interest. Under section 28 companies managing mutual funds should have a person responsible for monitoring the compliance of the company with the regulations.

Executing these obligations envisaged fine for a legal person and responsible person in the legal entity as well as a temporary prohibition of activity of the company. Despite the existence of numerous types of codes pertaining to business in the country, the question is how they are implemented in practice. 
The introduction of a code of ethics in a company is the first step to promote integrity systems, but it will not bear fruit if the company did not pay attention to the education of employees and other stakeholders about the Code and its application in daily operations unless introduce rewards and sanctions in this respect or disrespect in human resource policies unless develop channels for providing advice and submitting complaints (SCCP, 2015). It is open to question how many models and codes are adjusted and accepted by the companies. Three general codes of business ethics mentioned above are not subject to special monitoring mechanisms of their application to sanction the eventual visual deviations. Part of the mentioned branch or professional codes have established bodies examined cases of possible deviation from the provisions of codes and having the opportunity to establish corrective measures. However, in the survey they were not located published data on the activity of these bodies and their results in terms of ensuring compliance with the provisions of the codes, which leaves open questions about their functionality.

\section{PRACTICE OF ANTI- CORRUPTION MEASURES FOR CORPORATE SECURITY IN WESTERN COUNTRIES AND US}

\subsection{Pre-employment polygraph}

Pre-employment polygraph is a process used by employers to assist them in determining the suitability, reliability, honesty and integrity of the worker. It is only one phase of most stages of the recruitment process designed to help you check all information of a job seeker provided during the recruitment process 80 (eg, forms, questionnaires and previous interviews). The examiner polygraph will review the questionnaire to the applicant to work in detail to ensure that you find all relevant and appropriate information. It is important to understand that people expect perfection, but expect a high degree of honesty and integrity for past behavior and activities. Although it is imperative to find the sincerity of all the information at the time of filing, are often applied for additional information or unexpected exposure to situations that need to be disclosed. This phase will be the last opportunity to demonstrate the level of honesty and integrity (Cumming, A., 2009). Questions about education or previous work experience will be chosen by the examiner polygraph, based on the answers given during the review. The test will check whether or not deliberately reserved any information concerning the involvement in any criminal or corrupt activities. The entire process of examination of education and prior work experience should not take more than four to five hours to complete the examination. If the candidate retains information or fails to cooperate, the length of the examination can be significantly longer.

\subsection{The role of internal investigations}

Deciding whether to undertake an internal investigation is a key part of the response of the organization to detect or there is a suspicion of corruption. All internal investigations should adhere to the principles of natural justice, confidentiality, rules of evidence and standards of regulations, legal and policy compliance, and health and safety.

The purpose of an internal investigation to find out what happened and to identify that action is needed to protect the organization from loss or damage. 
The internal investigation is practice to establish the facts, not a trial or tribunal. The investigation can give the findings and recommendations, but it is not the role of the detective act on these findings and recommendations. Poorly conducted an internal investigation may result in corrupt officials go unpunished, persons under investigation being treated unfairly and wasted resources of the organization. The organization should investigate the existence or nonexistence of "serious corruption" and "systemic corruption" (Carberry, C., Deane, R., 2016). Several studies found that there is inadequate capacity internal investigation including insufficient training and experience by managers in response to reports of corrupt behavior which is a factor that corruption occurs or continues.

Senior management should ensure that his organization has a policy and procedure for conducting internal investigations and / or be outsourced. The purpose of this policy is to ensure that internal investigations are guided by consistent principles and rules, and thus to avoid any accusations of bias. The procedure should ensure the appointment of an external examiner for investigation if necessary, such as when potential internal investigators have a conflict of interest, appear allegations involving senior or agency that has the capacity to conduct its own investigation (eg because it is too small).

\section{CONCLUSION}

Local regulations shall require companies to dispose of and to submit data on their ratings, but usually not beneficial ownership. Register of companies and other legal entities are also limited to keeping data on nominal property. Only the companies from certain activities with increased risk for money laundering, as defined by the law on prevention of money laundering and other proceeds from crime and terrorist financing are required for collecting data on beneficial ownership of customers. Additionally there are mechanisms for the control of businesses, which, regardless of ownership, can avail of a particular individual, or an individual acting through a legal person to exercise effective control over the companies. Prescribing minimum standards for organizational program for adherence to laws and regulations, and conduct, upon which companies may be eligible for reduced sanction for committing illegal acts. Amendment patterns of ethical codes and codes of good corporate governance with detailed provisions on:

»Prevention of Corruption in donations, sponsorships and public procurement;

»Encourage reporting of suspicions of corruption and other illegal activities, establishing procedures and reporting channels, the protection of persons performing such reporting and sanctions against retaliation or discrimination against such persons;

»Monitoring and compliance system for codes at company level, and also for level of industry, region or sector.

Experiences in the US and Western developed countries show that the most common anti-corruption measures taken to ensure corporate security are internal investigations and polygraph employment. The investigations carried out by the company itself or through outsourcing if the company does not have adequate capacity. Polygraph employment should show whether a job seeker has been involved in previous criminal activity and corruption. 
(JPMNT) Journal of Process Management - New Technologies, International

Vol. 5, No 2, 2017.

\section{References}

[1] Business Anti-Corruption Portal, (2016), Macedonia country profile, Denmark;

[2] SCPC (2015), National Programme for Prevention and Repression of Corruption 2011-2015, Skopje;

[3] European Commission (2016), the EU anticorruption report from the Commission to the Council and the European Parliament, Brussels;

[4] Law on the Budget ("Official Gazette No. $180 / 2013)$;

[5] Law on Prevention of Corruption (Official Gazette 28/2002);

[6] Public Procurement Act (Official Gazette 136/2007);

[7] Kambovski V., Naumovski, P. (2002) Corruption - the greatest social evil and a threat to the rule of law, Skopje;
[8] Nuredinoska, E; Sazdevski M. Gjuzel, B. (2014), Report on assessment of corruption in Macedonia. Macedonian Center for International Cooperation;

[9] UN, (2016), The United Nations Convention against Corruption: A Resource Guide on State Measures for Strengthening Corporate Integrity, New York;

[10]Center for Studying Democracy (CSD), (2016), Report on Corruption, Contraband and Organized Crime in Southeast Europe, Sofia.

[11]Cumming, A., (2009), Polygraph Use by the Department of Energy: Issues for Congress, by Alfred Cumming, Congressional Research Service, New York.

[12] Carberry, C., Deane, R., (2016), Corporate Internal Criminal Investigations, Boston. 